\title{
Risk of Material Misstatement in Fluctuated Economic Environments: The Case of Greece
}

\author{
Stamatios Dritsas ${ }^{1} \&$ George Petrakos ${ }^{1}$ \\ ${ }^{1}$ School of Economics and Public Administration, Panteion University, Athens, Greece \\ Correspondence: George Petrakos, Dept. of Public Administration, Panteion University, Athens, Greece.
}

Received: January 4, 2018

Accepted: May 25, $2018 \quad$ Online Published: May 28, 2018

doi:10.5539/ibr.v11n6p243

URL: https://doi.org/10.5539/ibr.v11n6p243

\begin{abstract}
The aim of this paper is a) to investigate the relationship between the business risk and the risk of material misstatement at an overall financial level and b) to determine the dependencies between the risk of material misstatement and selected risk factors affecting pervasively the financial statements and many assertions. The study was based on data collected from a statistical survey among experienced statutory auditors employed by the five largest international audit firms in Greece. The research suggests a statistically significant relationship between the business risk and the risk of material misstatement at the overall financial statements level. Furthermore, although the majority of the survey participants believes that the recent financial crisis in Greece affected their assessments on going concern risk and the risk linked to accounting estimations substantially, the dependencies between those two risks and the risk of material misstatement at an overall financial statements level are not validated by the survey data.
\end{abstract}

Keywords: audit risk, financial statements, risk assessment, risk of material misstatement

\section{Introduction}

Audit risk is a function of the risk of material misstatement and the detection risk. Risk of material misstatement may exist both at the overall financial statements level and at the assertions level. During the planning phase of the audit, the auditors perform risk assessment of risks of material misstatement at the financial statements and assertion level in order to decide about the audit strategy and approach. The main purpose of this study is to quantitatively examine the relationship between the business risk and the risk of material misstatement at an overall financial level through a large scale empirical survey among Greek auditors. Furthermore, the paper reaches a quantitative assessment of the level and discusses the nature of the relationship between the risk of material misstatement and selected risk factors, which affect pervasively the financial statements as a whole and they have a potential effect on many assertions. These factors, selected with the criteria mentioned above, are the appropriateness of the "going concern" assumption, the material misstatement due to fraud, the related parties transactions and the accounting estimates.

The dramatic changes in the business environment due to the recent financial crisis in Greece served as the natural experimental basis for a statistical assessment of these relationships. The quantitative part of this study was based on the empirical research designed to gather documentation regarding the changes in risk assessment at an overall financial statements level. The statistical survey was evaluated by experienced statutory auditors employed by the big five international audit firms in Greece, in the course of financial statements audits of commercial and manufacturing entities located in the country, during the period before and after the financial crisis.

Audit planning and audit procedures have been empirically researched as to several issues. Many prior studies (Dusenbury, Reimers \& Wheeler, 2000; Messier \& Austen, 2000; Ritchie \& Khorwatt, 2007; Bloomfield, 1995; Quadackers, Mock \& Maijoor, 1996; Quick, 2012) studied the functional relationship among the variables of the Audit Risk Model (ARM) or examined the dependencies between the entity's environment as it is reflected in the business risk and in the designed and implemented audit approach. However, most studies regarding the interrelations of audit risk components have been focused on ARM variables at the assertions level and they mainly examine the inherent and control risk as two different risk components. In addition, a significant volume of prior research on ARM studies (Dusenbury et al., 2000; Messier \& Austen, 2000; Ritchie \& Khorwatt, 2007; Bloomfield, 1995), has been based on US professional standards of auditing and the US GAAS approach. After 
1983, when SAS No 47 was published, replacing SAS 39 (AICPA, 1983), both approaches, US GAAS and ISAs, converged at a quite similar approach regarding risk components and their assessment. Furthermore, since 2006, when SAS 47 was replaced by SAS 107 (AU - 312), even the remaining differences between US GAAS and ISAs were eliminated (AICPA, 2012).

Given the aforementioned clarifications regarding the relevancy of prior studies, the experiment of Dusenbury et al. (2000), conducted in US environment, has to be noted. The authors of this study tested the conditional dependencies among the assessed audit risk components (inherent risk, control risk and detection risk). For the purposes of their study, they developed a sequential linear modeling process in order to add previously assessed risk components to the audit risk model and they have finally concluded on the conditional nature of audit risk components assessment. Messier and Austen (2000) supported the existence of a positive relationship between inherent and control risk. Their conclusion was based on the indirect US GAAS guidelines as well as on other causal relationships related to entities' environment, internal controls and potential misstatements. They also claim that a number of identification factors related to inherent and control risk are common in both risk components.

Following the positive relationship between inherent and control risk concluded by Messier and Austen (2000), Ritchie and Khorwatt (2007) conducted an empirical study regarding the understanding of the AR components and their application by professional Libyan auditors in practice. This study focused on Libyan auditors' assessment regarding the inherent and control risk and has also been based on US GAAS guidelines regarding ARM. The evidence gathered in the course of this study reinforced the view that inherent and control risk were assessed independently. Further on, it was noted that auditors in Libya were aware of the risk differentials depending on the level of account and were cognizant of factors normally associated with potentially high and low risk levels. Bloomfield (1995) suggested that an accurate assessment of inherent risk is crucial for an efficient and effective audit. Further, he concluded that the accuracy of the auditor's risk assessment is influenced by the risks of unintentional errors, the players' incentives, the precision of the auditor's data and regulatory bounds on detection risk.

In the European environment, Quadackers et al. (1996) examined the variability in audit risk and audit programs using data from eight clients of four Dutch audit firms. This study reports substantial variation in audit risk factors both between audited entities and among the audit risk factors per entity. In addition, the research identified some degree of risk variation over time. Furthermore, it suggested that variability of risk factor assessments over time is higher than variability of risk model variable assessments over time. Finally, the authors concluded that audit programs (which in our research are considered the "auditors' responses to assessed risks") differ substantially between audited entities and (to a lesser extent) over time.

Quick (2012) examined the potential effects of selected proposals on audit quality in the light of prior research findings, with audit procedures strictly based on ISAs. Among others, the author concluded that when increased emphasis is given on substantive audit procedures, this means that they give up the business risk audit approach, at least in parts, or they increase the level of assurance. This procedure may not be beneficial to audit quality. Tsipouridou and Spathis (2014) studied the relationship between the audit opinions and earning management by taking into consideration the economic environment in Greece, since the financial crisis in the country became visible in 2009. Their research examined two categories of qualified audit opinions (qualified for the going concern uncertainty and qualified for other issues) in a sample of Greek Listed Companies for the period 2005 2011. The authors reached the conclusion that the auditors' decision to issue qualified opinions for other reasons could be explained by the type of audit opinion issued in the previous year.

The aim of this paper is to make a twofold contribution to the literature. First, the study is designed so as to quantitatively examine the relationship between the business risk and the risk of material misstatement at an overall financial level. Second, it tries to determine the existence, level and nature of the relevance of the risk of material misstatement with selected risk factors affecting pervasively the financial statements and many assertions. In this respect, the study assesses the direct and indirect relationship of the selected risk factors with the business risk as well as with the risk of material misstatements at the overall level. The selected risk factors under examination refer to: a) the appropriateness of "going concern" assumption (GC), b) material misstatement due to fraud (F), c) related parties transactions (RPT) and d) accounting estimates (AES).These factors have been considered key risk factors in the case of Greece and they have been selected due to their pervasive effect on the financial statements as a whole and their potential effect on many assertions.

The paper focuses on the external business risk (BR) that is limited and corresponds only to the business and economic environment of an entity. The empirical survey investigates the audit practicing in Greece and 
approaches the overall business risk and its changes, due to the factual financial conditions of the local economic and business environment, before and after the occurrence of the recent financial crisis. It should be highlighted that, for the purposes of this study, business risk has been considered tobe the risk which is entirely related with the factual economic and business environment in Greece and as such reflects the key changes due to the recent financial crisis. Changes or fluctuations of other components of business risk in Greece, during the period under examination, are not considered as key or material factors and thus they are not investigated as additional variables.

The remainder of the paper is structured as follows: Section 2 presents the abstract model used as well as the main hypotheses tested. Section 3 outlines the design of the survey, the target population, the sampling methodology and the questionnaire structure. In addition, this chapter discusses the methodology of the statistical data analysis and summarizes its results. Finally, section 4 briefly discusses and concludes the research findings.

\section{The Model and the Research Hypotheses}

The theoretical and conceptual framework used for the purposes of this study has been based on ISAs issued by IFAC and adopted as the unique professional standards framework for audit practice in Greece since 2004. The examination of the sensitivity of the assessment of RMM to BR and its interrelation with specific risk factors has been examined based on a model of seven variables tailored to the needs of the research. This model constitutes an abstract of a generic model developed in the course of a broader empirical research investigating the interrelations of the assessments of audit risk components in Greece (Dritsas, 2014). This abstract model considers RMM as a dependent variable while BR and the four selected risk factors (GC, F, RPT, AES) have been treated as independent variables. The model adopted for the purposes of the specific study is illustrated in figure 1.

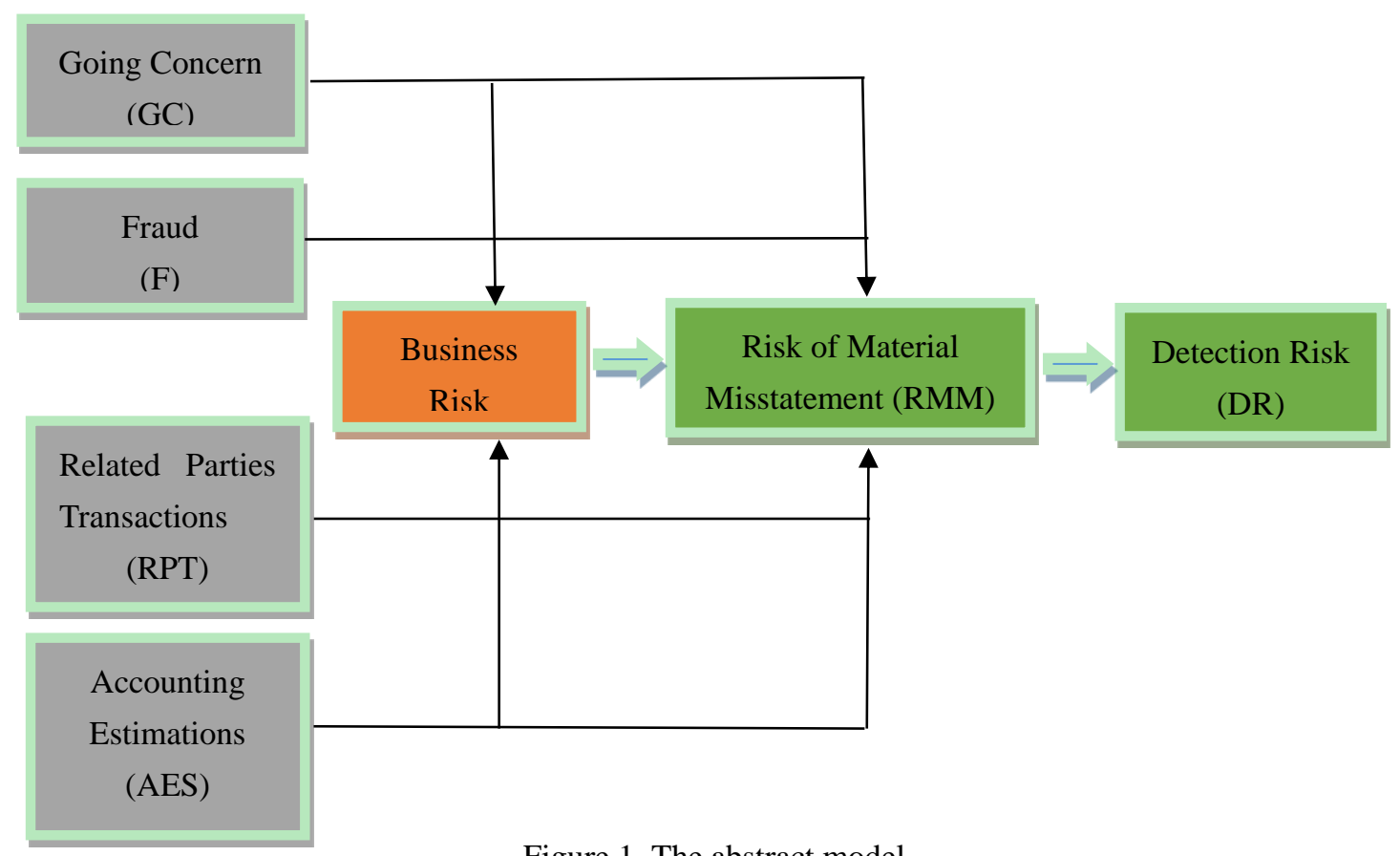

Figure 1. The abstract model

Two main groups of research hypotheses are tested in this paper using the collected survey data. The first group (A) consists of hypotheses regarding changes in the level of risk of all examined factors before and after the occurrence of the economic crisis. Each research hypothesis is expressed in a standard statistical hypothesis form as

$H_{A I}$ : The majority of auditors report an increase in risk of material misstatement and of the $x$ factor assessment after the occurrence of the financial crisis, where $x=\{G C, F, R P T, A E S\}$

The second group (B) consists of hypotheses regarding the pairwise relationship of the selected risk factors with RMM. These research hypotheses are expressed as

$H_{B I x}$ : The assessment of the risk of material misstatement at an overall level and the risk of $x$ factor assessment are statistically dependent on the auditors' population, where $x=\{G C, F, R P T, A E S\}$ 
The corresponding null hypotheses (in the A and B group) are expressed as "no increase in RMM and risk of $\mathrm{x}$ factor" and "RMM and the risk of $\mathrm{x}$ factor assessment are independent", respectively.

\section{Statistical Survey Design and Results}

The target population of the survey consists of all auditing practitioners holding the licence of statutory auditor according to the national legislation (adopting the respective EU Directive), employed by the five large international firms, PWC, EY, Deloitte, KPMG and Grand Thornton in Greece. The official register of the population under study was made available by the Hellenic Accounting and Auditing Oversight Board (HAASOB) and it was properly updated. A stratified random sample was drawn from this population so that results could be generalized for the whole population. Ordinal type of measurement was used in a structured questionnaire of 5 barrel questions for data collection. These questions have been designed so as to draw conclusions regarding the structural relationships of the variables RMM, BR, GC, F, RPT and AES.

The data gathered refers to the assessments of RMM, BR, GC, F, RPT and AES in the course of financial statements audits performed under ISAs to Greek commercial and manufacturing companies, for the period before and after the financial crisis in Greece. Therefore, it was also suitable for individually identifying any significant changes in the risk factors between the two time periods. The pilot survey conducted prior to the main one, the low non-response rate and the validation routines executed in the final database ensured the quality of the data in hand. Specifically, the pilot survey consisted of numerous extensive interviews with highly experienced domain experts and resulted in significant changes and improvements in the questionnaire structure and content.

Initially, we investigated the effect of the financial crisis in RMM and the other four risk factors under study, namely GC, F, RPT and AES. The primary data was handled in a way that differences in risks before and after the occurrence of the financial crisis were calculated and coded in three levels. Consequently, this effect was measured in a 3-point ordinal scale as decrease (1), unchanged (2) and increase (3) for all five variables reflecting the estimated changes in the level of risk. Statistical Analysis was performed using $R$ programming language and software environment for statistical computing and graphics, version 3.2.2. The main descriptive analysis results are briefly summarized in table 1.

Table 1. Effect of the financial crisis in RMM, GC, F, RPT, AES

\begin{tabular}{llll}
\hline \multicolumn{4}{l}{ Relative Frequencies per risk factor } \\
\hline Variables & Decrease(1) & Unchanged(2) & Increase(3) \\
\hline RMM & 0.04 & 0.27 & 0.69 \\
GC & 0.00 & 0.10 & 0.90 \\
F & 0.10 & 0.50 & 0.40 \\
RPT & 0.05 & 0.49 & 0.46 \\
AES & 0.01 & 0.18 & 0.81 \\
\hline
\end{tabular}

Regarding the Risk of Material Misstatement, the majority (69\%) of the auditors participating on the survey believe that the financial crisis caused a measurable increase in RMM. The percentage of auditors in the sample who report increasing risk after the occurrence of the crisis becomes even larger for GS (90\%) and AES (81\%). On the other hand, auditors were almost equally divided in those who state an increase in the level of the remaining risk factors (F and RPT) and those who report no effect of the financial crisis on them. Trying to make inference regarding the auditors' population, we constructed the confidence intervals for the three variables RMM, GC and AES as presented in Table 2. The results of our analysis clearly support the hypothesis that the majority (more than $50 \%$ of the total population) of the auditors believe that the risks associated with RMM, GC and AES have been increased in the years of financial crisis, at a 95\% level of confidence. The same results are produced from the binomial test for proportions, at a 5\% significant level.

Table 2. 95\% Confidence Intervals for RMM \& AES

\begin{tabular}{llll}
\hline \multicolumn{4}{l}{ Interval Estimation at 0.95 confidence per risk factor } \\
\hline Variables & Increase \% & Marginal Error & Confidence Limits \\
\hline RMM & 0.69 & 0.105 & $(0.585-0.795)$ \\
GC & 0.90 & 0.068 & $(0.832-0.968)$ \\
AES & 0.81 & 0.089 & $(0.721-0.899)$ \\
\hline
\end{tabular}

Searching for dependencies among risks, we paired RMM with all the remaining risk variables. Specifically, for each pair we construct a contingency table with $r$ rows and c columns, consisting of rxc cells, where $\mathrm{n}_{\mathrm{ij}}, \mathrm{i}=1, \ldots, \mathrm{r}$ and $\mathrm{j}=1, \ldots, \mathrm{c}$ are the counts in the ij cell. Next, we perform $\chi^{2}$ test for independence by first calculating the $\chi^{2}$ statistics as

$$
\chi^{2}=\sum_{i j} \frac{\left(n_{i, j}-\frac{n_{i .} n_{. j}}{n_{. .}}\right)^{2}}{\frac{n_{i . . . j}}{n_{. .}}}
$$


and then we calculate the corresponding p-value. Finally we calculate Cramer's V as a function of $\chi^{2}$ statistics

$$
V=\sqrt{\frac{\chi^{2} / n}{\min (c, r)-1}}
$$

in order to measure the association between the two risk factors. Cramer's $V$ take values from 0 to 1 with values closed to one referring to strong association. Summarizing the results of all four chi-square tests for independence, we record chi-square statistics, p-value and level of significance, reported in table 3 . For those variables found to be significant at any level, we further calculate Cramer association coefficient.

Table 3. Test for independence and Cramer association for RMM

\begin{tabular}{llllll} 
& Variables & $\chi^{2}$ statistics & p-value & sig. & Cramer's V \\
\cline { 2 - 6 } GC & 2.6177 & 0.1057 & - & \\
F & 10.5962 & 0.005001 & $* * *$ & 0.3709627 \\
RPT & 10.0291 & 0.001541 & $* * *$ & 0.3608984 \\
* sig. at 0.1, & AES & 1.2849 & 0.257 & - & \\
\cline { 2 - 6 } sig at $0.05, \quad * * *$ sig at 0.01, & - no sig & &
\end{tabular}

According to these results RMM shows a statistically significant association with F and PRT at 0.01 level, measured by Cramer's V as 0.37 and 036 respectively. The other two variables GC and AES do not show a statistically significant association with RMM at either 0.05 or 0.1 significant level.

\section{Summary and Conclusion}

Based on the survey data, the majority $(69 \%)$ of the participants have declared that the recent financial crisis in Greece affected substantially (evidently shifted in a higher level) the risk of material misstatement, as it is assessed in the course of the financial statements audits for commercial and manufacturing Greek companies, after the occurrence of the crisis. Furthermore, the documentation gathered would support the conclusion that the risk of the material misstatement at an overall financial statement level and the risk of the material misstatement due to fraud as well as due to related parties transactions could not be considered pairwise independent variables. It could be noted that the above- mentioned outcome is consistent with the framework of ISAs regarding the relationship between the assessment of material misstatement at financial statement level and the risk of fraud (IFAC, 2014), as well as the risk of significant misstatement due to related parties transactions. However, the empirical data gathered do not provide sufficient evidence to conclude the statistical relevance between the financial crisis in Greece (business risk) and the above-mentioned risk factors.

In addition, the survey does not provide sufficient documentation in order to draw the same conclusion regarding the relevance between the risk of material misstatement at an overall financial statement level and the risks related to going concern assumption and accounting estimates. Nevertheless, the vast majority (90\%) of the participants believe that the recent financial crisis affected directly and substantially the assessment regarding the risk of an inappropriate adoption of the going concern assumption. Accordingly, a large majority $(81 \%)$ of the participants supported the argument that the recent financial crisis affected directly and substantially the assessment of the risk related to accounting estimations. In both cases, evidently these risks are considered higher after the crisis occurrence.

The majority of the survey participants declared that the recent financial crisis in Greece affected their assessment of the inappropriate adoption of the going concern assumption and the risk of material misstatement due to accounting estimation substantially. However, the survey data did not provide sufficient documentation in order to conclude pairwise statistically significant dependency between those two risks and the risk of material misstatement at financial statements level. It seems that the auditors tend to concentrate on specific risk factors with pervasive effect on the financial statements because of their dependency on the risk of material misstatement and not necessarily because of their direct sensitivity to business risks.

It should be noted that, in terms of planning and execution of audit procedures, this ascertainment does not necessarily mean that the assessment of risk of material misstatement at financial statement level would be considered as independent from the risks of inappropriate adoption of going concern assumption as well as the risks of potential misstatement arising from accounting estimations. It should be highlighted that our research provided sufficient empirical data regarding the relevance of these two factors and the assessed business risk while at the same time the relevance of business risk with the assessment of the risk of material misstatement has been already sufficiently documented.

Additionally, our work has not been extended into investigating the audit procedures designed or performed based on the above-mentioned assessments, in order to draw conclusions thereon (DR). Eventually, it could not be appropriate to conclude that in case of risk factors affecting pervasively the financial statements and at the same 
time being sensitive to business risks, the audit strategy tends to be limited only to those factors that are directly related to the assessment of risk of material misstatement.With regard to the relevance between the other two risk factors (fraud and related parties transactions) and the assessments of risk of material misstatement as well as the business risk, the statistical analysis showed that although these two risk factors are not substantially relevant to the business risk, their relationship with the assessment of risk of material misstatement could be proved to be statistically significant.

The empirical documentation gathered from our research in Greece sufficiently supports the statement that the significant changes in business risks would affect the assessment of specific risk factors with pervasive effect on financial statements. In the latter case, the indirect effect is related to the assessment of the risks of material misstatement. Based on the discussion above, we reasonably conclude that the recent financial crisis in Greece, as it is reflected in business risk associated with audited entities, affected substantially the risk of material misstatement at the overall financial statements level, assessed in the course of their financial statements audits that have been performed after the occurrence of the crisis. In addition, this financial crisis affected directly or indirectly (through its relevance to the risk of material misstatement) main risk factors with pervasive effect on the financial statements.

\section{References}

American Institute of Certified Public Accountants (AICPA). (1983). Statement on Auditing Standards No 47: Audit Risk and Materiality in Conducting an Audit. New York: American Institute of Certified Public Accountants.

American Institute of Certified Public Accountants (AICPA). (2012). Substantive Differences between the International Standards on Auditing and Generally Accepted Auditing Standards. New York: American Institute of Certified Public Accountants.

Bloomfield, R. (1995). Strategic Dependence and Inherent Risk Assessments. The Accounting Review, 70(1), 71-90. Retrieved from http://www.jstor.org/stable/248389

Dritsas, S. (2014). Audit Risk Model: An empirical study of functional relationship between the risk components in Greece (Doctoral dissertation, Dept. of Public Administration, Panteion University of Social and Political Studies, Athens, Greece). Retrieved from: http://pandemos.panteion.gr/index.php?op=record\&pid=iid:8190\&lang=el

Dusenbury, R. B., Reimers, J. L., \& Wheeler, S. W. (2000). The Audit Risk Model: An Empirical Test of Conditional Dependencies among Assessed Component Risks. Auditing: A Journal of Practice \& Theory, 19(2), 105-117. https://doi.org/10.2308/aud.2000.19.2.105

International Federation of Accountants (IFAC). (2014). Handbook of International Quality Control, Auditing, Review, Other Assurance and Related Services Pronouncements. IFAC, 2014 edition, International Auditing and Assurance Standards Board (IAASB).

Messier Jr., W. F., \& Austen, L. A. (2000). Inherent risk and control risk assessment: evidence on the effect of pervasive and specific risk factors. Auditing: A Journal of Practice and Theory, 19(2), 119-131. https://doi.org/10.2308/aud.2000.19.2.119

Quadackers, L., Mock, T. J., \& Maijoor, S. (1996). Audit risk and audit programmes: archival evidence from four Dutch audit firms. European Accounting Review, 5(2), 217-237. https://doi.org/10.1080/09638189600000014

Quick, R. (2012). EC Green Paper Proposals and Audit Quality. Accounting in Europe, 9(1-2), 17-38. https://doi.org/10.1080/17449480.2012.664398

Ritchie, B., \& Khorwatt, E. (2007). The attitude of Libyan auditors to inherent control risk assessment. The British Accounting Review, 39, 39-59. https://doi.org/10.1016/j.bar.2006.11.001

Tsipouridou, M., \& Spathis, C. (2014). Audit opinion and earnings management. Accounting Forum, 38, 38-54. https://doi.org/10.1016/j.accfor.2013.09.002

\section{Copyrights}

Copyright for this article is retained by the author(s), with first publication rights granted to the journal.

This is an open-access article distributed under the terms and conditions of the Creative Commons Attribution license (http://creativecommons.org/licenses/by/4.0/). 